\title{
The Way Day Breaks
}

\section{Emily Duggan ${ }^{1}$}

Received: 27 November 2020 / Accepted: 18 January 2021 / Published online: 24 February 2021

(C) The Author(s) 2021

"This is the way day breaks in Bowditch Hall at Mclean's" Robert Lowell, "Waking in the Blue"

i.

Waking in the black that comes for the living only before dawn, we're wrung from our beds like damp hand towels: used; leaking blood (some of us). They take our weights \& vitals in vials, one by one; the rest restlessly await our next \& nightly judgment, draped across the vile mauve milieu couches like what the purple sea coughs up, looking at (without seeing) the five A.M. news:

eating disorders, the newscaster claims, happen most often to good people. This roomful of good people (what better collective noun for us than this?) giggles, or nearly cries. Leslie Nielsen dies quietly \& surely in the night. \& a boy my age, already dead, falls from the airplane's wheel well in real time into a nearby city, where a fellow runner finds his body.

ii.

Perfection has always been the story my body has wanted to tell $\&$ for everyone who has ached to understand how perfection can align so intuitively with self-destruction, there is someone who has told me they'd kill for my control.

Emily Duggan

Boston, MA, USA iii.

Well -

I tried.

iv.

Waking in the white that comes for the dead only before waking, everything is still, the same, another morning at Mclean's, the steady drag of traffic on the pre-light highways, the blackened cars moving behind their headlights like the baggage ghosts carry past,

$\&$ all I can see

is the boy from the plane:

my age. The anguish

on that runner's face:

their hell. \& I,

who half my life have sleepwalked

into the sky, wake up halfway to the ground, eyes ripped wide:

v.

this is not the story I want to live to tell.

vi.

I am sick to death of wanting to die. I want all that time back. I want to burst back in time, cradle the soft, fearful corpse-in-waiting I have been until they feel safe inside those rabbit bones - home. \& alive, for the first time. But I don't want to die not today. Tomorrow - yes - FINE - 
vii.

but today

viii.

I am standing up \& climbing back

inside the airplane. I'm taking us in

for a safe landing. I want all the pieces

of me together at the end,

so my discoverers can say,

AHA! So these are the hands with which

they dismantled the murder machine

of their mind. These are the legs

that kicked back. \& these-

THESE -

etched around their eyes

like the rings of a tree-

these are the years they lived after

in whatever approximates peace:

that which runs parallel to perfection,

equivalent but untouching.

\section{Poet's statement:}

Written in the first person to illuminate the speaker's authority on their experience of the poem's content, I hope this piece can prove valuable in providing one perspective from a person in treatment on the potentially transformative nature of psychiatric care.

\section{Declarations}

Disclosures The author states that there is no conflict of interest.

Open Access This article is licensed under a Creative Commons Attribution 4.0 International License, which permits use, sharing, adaptation, distribution and reproduction in any medium or format, as long as you give appropriate credit to the original author(s) and the source, provide a link to the Creative Commons licence, and indicate if changes were made. The images or other third party material in this article are included in the article's Creative Commons licence, unless indicated otherwise in a credit line to the material. If material is not included in the article's Creative Commons licence and your intended use is not permitted by statutory regulation or exceeds the permitted use, you will need to obtain permission directly from the copyright holder. To view a copy of this licence, visit http://creativecommons.org/licenses/by/4.0/.

Publisher's Note Springer Nature remains neutral with regard to jurisdictional claims in published maps and institutional affiliations. 